\title{
Penyuluhan Hukum Pendaftaran Izin Usaha Mikro Kecil (IUMK) di Kota Semarang melalui Sistem Online Single Submission (OSS)
}

\author{
${ }^{1}$ Amin Purnawan*, ${ }^{1}$ Akhmad Khisni, ${ }^{2}$ Siti Ummu Adillah \\ ${ }^{1}$ Prodi Magister Kenotariatan, Fakultas Hukum, UNISSULA, Semarang, Indonesia \\ ${ }^{2}$ Prodi Ilmu Hukum, Fakultas Hukum, UNISSULA, Semarang, Indonesia \\ *Corresponding Author \\ Jl. Raya Kaligawe KM. 4 Semarang, Jawa Tengah, Indonesia \\ Telp. (+6224) 6583584, Fax (+6224) 6582455 \\ Email: amin.p@unissula.ac.id.

$\begin{array}{cccc}\text { Received: } & \text { Revised: } & \text { Accepted: } & \text { Published: } \\ \text { 25 April 2020 } & \text { 3 May 2020 } & \text { 17 May 2020 } & 31 \text { May 2020 }\end{array}$

\begin{abstract}
Abstrak
Penyuluhan Hukum dan Pendampingan tentang Pendaftaran Izin Usaha Mikro Kecil (IUMK) di Kota Semarang melalui Sistem Online Single Submission (OSS) berdasarkan Peraturan Pemerintah Nomor 24 Tahun 2018 ini, berangkat dari hasil penelitian yang menunjukkan bahwa problematika pelaksanaan pendaftaran legalitas usaha UMKM melalui Sistem OSS di Kota Semarang, terutama karena kurangnya sosialisasi dan edukasi kepada pelaku UMKM. Pelaksanaan pengabdian masyarakat dalam bentuk penyuluhan hukum dan pendampingan kepada sejumlah 35 pelaku UMKM di Kecamatan Semarang Selatan. Tingkat antusiasme peserta cukup tinggi dimana peserta banyak mengajukan pertanyaan seputar legalitas usaha dan berminat untuk mengurus legalitas usahanya. Ada salah satu peserta yang membagikan pengalamannya mengurus legalitas usahanya dan manfaat yang telah dirasakan dalam meningkatkan pertumbuhan usaha. Pengabdian masyarakat ini bertujuan untuk meningkatkan kesadaran hukum pelaku UMKM untuk mengurus legalitas usahanya. Metode peningkatan kesadaran hukum dengan memberikan penyuluhan dan pendampingan. Adapun materi sosialisai meliputi UU No. 20 Tahun 2008 tentang UMKM dan Perda No. 13 Tahun 2013 tentang Pemberdayaan UMKM; Peraturan Pemerintah Nomor 24 Tahun 2018 tentang Pelayanan Perizinan Berusaha Terintegrasi Secara Elektronik/Online Single Submission (OSS). Pelaku Usaha Mikro, Kecil, dan Menengah sebagai salah satu pelaku pembangunan ekonomi di daerah perlu diberdayakan melalui pengembangan sumber daya manusia, dukungan permodalan, produksi dan produktifitas, perlindungan usaha, pengembangan kemitraan, jaringan usaha dan pemasaran serta legalitas usahanya melalui Online Single Submission (OSS). Hasil penyuluhan dan pendampingan menunjukkan peningkatan pemahaman dan kesadaran hukum UMKM untuk mengurus legalitas usahanya.
\end{abstract}

Kata Kunci: Izin Usaha; Pendaftaran; Penyuluhan Hukum; Sistem OSS 


\begin{abstract}
Legal Counseling and Assistance on the Registration of UMKM Business Legality in Semarang through the Online Single Submission System (OSS) based on PP Number 24 of 2018 departs from the results of research showing that the problematic implementation of the registration of the legality of MSME businesses through the OSS System in Semarang City, mainly due to lack dissemination and education to SMEs. Implementation of community service in the form of legal counseling and assistance to a number of 35 SMEs in the South Semarang District. The level of enthusiasm of the participants was quite high where participants asked many questions about the legality of the business and were interested in taking care of the legality of the business. There was one participant who shared his experience taking care of the legality of his business and the benefits that have been felt in promoting business growth. This community service aims to increase the legal awareness of SMEs to take care of the legality of their business. Methods of increasing legal awareness by providing counseling and assistance. The socialization material includes Law No. 20 of 2008 concerning UMKM and Perda No. 13 of 2013 concerning Empowerment of MSMEs; Government Regulation Number 24 of 2018 concerning Online Single Submission (OSS) Licensing Services. Micro, Small and Medium Enterprises as one of the economic development actors in the regions needs to be empowered through human resource development, capital support, production and productivity, business protection, partnership development, business and marketing networks and business legality through Online Single Submission (OSS). The results of counseling and mentoring showed an increase in understanding and legal awareness of MSMEs to take care of the legality of their business.
\end{abstract}

Keywords: Business Legality; Legal Education; OSS System; Registration

\title{
PENDAHULUAN
}

Penyuluhan hukum dan pendampingan tentang Pendaftaran Izin Usaha Mikro Kecil (IUMK) di Kota Semarang melalui Sistem Online Single Submission (OSS) berdasarkan Peraturan Pemerintah Nomor 24 Tahun 2018 ini dilakukan dengan tujuan untuk meningkatkan kesadaran hukum pelaku UMKM agar memiliki izin usaha. Aspek legalitas yang memperhatikan kepentingan dunia usaha (business friendly) perlu dijadikan paradigma baru, apalagi di era revolusi industri 4.0 ini, kehadiran UMKM semakin diperlukan.

Peran negara adalah menyediakan kerangka regulasi yang efektif beserta mekanisme pengawasan dan penegakan hukum. Pemerintah harus mempertimbangkan kenyataan bahwa dukungan aspek legalitas tersebut sangat dibutuhkan bagi pelaku UMKM dimana pekerja berpendapatan rendah berada didalamnya.

Hasil penelitian Purnawan (2019) menunjukkan bahwa problematika pelaksanaan pendaftaran legalitas usaha UMKM melalui Sistem OSS di Kota Semarang, terutama karena kurangnya sosialisasi dan edukasi kepada pelaku UMKM yang mengakibatkan rendahnya tingkat kepatuhan hukum. 
Berdasarkan Permendagri No. 83 Tahun 2014, Pengertian IUMK adalah tanda legalitas kepada seseorang atau pelaku usaha/kegiatan tertentu dalam bentuk izin usaha mikro dan kecil dalam bentuk naskah satu lembar. IUMK diiharapkan dapat memberikan kepastian hukum dan menjadi sarana pemberdayaan bagi pelaku usaha mikro dan kecil dalam mengembangkan usahanya.

Perizinan Berusaha Terintegrasi Secara Elektronik atau Online Single Submission yang selanjutnya disingkat OSS adalah Perizinan Berusaha yang diterbitkan oleh Lembaga OSS untuk dan atas nama menteri, pimpinan lembaga, gubernur, atau bupati/wali kota kepada pelaku usaha melalui sistem elektronik yang terintegrasi.

Adapun tujuan diterbitkannya IUMK adalah:

1. Mendapatkan kepastian dan perlindungan dalam berusaha dilokasi yang telah ditetapkan;

2. Mendapatkan pendampingan untuk pengembangan usaha;

3. Mendapatkan kemudahan dalam akses pembiayaan ke lembaga keuangan bank dan nonbank;

4. Mendapatkan kemudahan dalam pemberdayaan dari pemerintah pusat, pemerintah daerah dan/atau lembaga lainnya.

IUMK pada hakikatnya menjadi nilai tambah dari sebuah UMK untuk menjamin statusnya di hadapan hukum dan mempermudah jika ingin melakukan pengembangan usaha. Apalagi di persaingan global seperti sekarang, izin resmi dan legal menjadi syarat mutlak agar bisa diterima. Lebih dari itu, IUMK juga menjadi bukti kepatuhan kita sebagai warga negara untuk ikut serta memajukan perekonomian bangsa melalui usaha mikro dan kecil.

Penelitian pendahuluan yang dilakukan Purnawan dan Adillah (2014) tentang pengembangan desain tax policy daerah berbasis keadilan untuk mendorong pertumbuhan UKM di Jawa Tengah menyimpulkan bahwa ketaatan pelaku UMKM untuk memenuhi aspek legal adalah hal yang strategis dalam menentukan keberhasilan usahanya.

Usaha mikro dan kecil yang dimaksud adalah usaha produktif milik orang perorangan dan/atau badan usaha perorangan yang memenuhi kriteria usaha mikro dan kecil yang diatur dalam UU No. 20 Tahun 2008. Kriteria usaha mikro dalam UU No. 20 Tahun 2008 adalah:

1. Memiliki kekayaan bersih paling banyak Rp 50.000.000,00 (lima puluh juta rupiah), tidak termasuk tanah dan bangunan; atau

2. Memiliki hasil penjualan tahunan paling banyak Rp 300.000.000,00 (tiga ratus juta rupiah)

3. Memiliki kekayaan bersih lebih dari Rp 50.000.000,00 (lima puluh juta rupiah) sampai dengan paling banyak Rp 500.000.000,00 (lima ratus juta rupiah), tidak termasuk tanah dan bangunan; atau

4. Memiliki hasil penjualan tahunan lebih dari Rp 300.000.000,00 (tiga ratus juta rupiah) sampai dengan paling banyak Rp 2.500.000.000,00 (dua milyar lima ratus juta rupiah)

Berdasarkan penelitian Sulistyo dkk (2014), UMKM di Indonesia merupakan salah satu pilar dalam perekonomian yang memiliki daya tahan terhadap gejolak ekonomi serta memiliki banyak bidang usaha yang dapat dikembangkan. Di sisi lain, terdapat beberapa kelemahan yang menjadi kendala pengembangan UMKM selain modal adalah modal intelektual (intellectual capital), kapabilitas manajemen, kapabilitas inovasi, entrepreneurship, produksi dan operasi, pemasaran termasuk customer relationship management dan legal.

Hukum dapat berfungsi sebagai alat rekayasa sosial (law is a tool of social engineering) (Wacks, 2009). Maka melalui politik hukum legalitas usaha, UMKM dapat didorong pertumbuhannya, dan apabila dikelola dengan baik, UMKM dapat meningkatkan produktivitas, meningkatkan income masyarakat dan menyumbang bagi pendapatan daerah. Sekalipun UMKM 
kontribusinya sangat besar dalam menopang ekonomi nasional namun tidak serta merta diikuti peningkatan pendapatan.

Hasil yang diharapkan dari pengabdian masyarakat ini adalah meningkatnya kesadaran hukum UMKM untuk mengurus izin usahanya. Pendekatan melalui penguatan aspek legalitas usaha dalam menghadapi masyarakat ASEAN, berdasarkan penelitian Purnawan (2011), perlu dilakukan agar mampu meraih keunggulan bersaing baik di tingkat nasional maupun internasional.

Pengabdian ini juga bertujuan ikut mengembangkan usaha mikro kecil khususnya di Kota Semarang terutama dari aspek legal, disamping itu perlu peningkatan sumber daya manusia, pemasaran, keuangan produksi, inovasi dan teknologi, ICT agar mampu menghasilkan kinerja yang optimal dan mampu memiliki daya saing baik lokal, nasional maupun internasional. Dengan adanya UMKM yang berkinerja tinggi, menurut Manurung (2008), maka akan mendorong peningkatan ekonomi masyarakat, meningkatkan lapangan kerja serta mengurangi tingkat kemiskinan.

Kelengkapan aspek legalitas usaha UMKM sangat penting dalam menciptakan kepastian hukum yang dapat mendukung kinerja dan keunggulan bersaing yang berkelanjutan khususnya usaha mikro kecil dan menengah. Menurut Sulistyo dkk (2014), keberhasilan dalam mengelola aspek legalitas, organizational knowledge assets, customer relationship management, dan innovation capability akan memberikan dampak pada keunggulan bersaing UMKM dan mampu memberikan kontribusi PDRB Jawa Tengah.

\section{METODE}

Pemecahan permasalahan pendaftaran IUMK di Kecamatan Semarang Selatan dalam meningkatkan pemahaman pentingnya legalitas usaha dan bagaimana tata cara pengurusannya dilakukan dengan beberapa pendekatan yang dilakukan secara bersama-sama, yaitu: 1) Ceramah dan tutorial, metode ini dilakukan pada kegiatan pelatihan dan pendampingan. Tim pelaksana pengabdian memberikan materi dengan metode ceramah disertai dengan tanya jawab serta tutorial untuk membantu peserta pengabdian. 2) Berbasis small group discussion, yaitu metode small group discussion adalah suatu cara mengajar yang dibagi menjadi beberapa kelompok. Setiap kelompok dibagi menjadi tiga sampai dengan lima orang (Fatimah, Kartika, \& Niyartama, 2012). Mereka bekerja sama dalam memecahkan masalah atau mempersiapkan syarat-syarat yang harus dilengkapi untuk memperoleh IUMK., setelah diadakan pelatihan dan pendampingan. Maka ada kegiatan semacam diskusi kecil sebagai follow up dari pelatihan sebelumnya. 3) Komprehensif, seluruh kegiatan pengabdian masyarakat dilakukan secara serentak terkait dengan Sumber Daya manusia (SDM), proses belajar, pelatihan dan pendampingan tenaga pengajar dan dibantu aparat kecamatan yang professional, 4) Learning by doing berbasis output. Hasil pengabdian yang dilakukan dengan proses pendampingan diharuskan menghasilkan terbitnya IUMK untuk masing-masing peserta penyuluhan. Selanjutnya, ketiga metode di atas diimplementasikan dalam empat tahapan, yaitu sosialisasi, peningkatan kompetensi, pendaftaran atau pelaksanaan kegiatan, serta monitoring dan evaluasi. Pelaksanaan kegiatan pengabdian dilakukan dalam bulan Desember 2019. Mitra adalah pelaku UMKM Kecamatan Semarang Selatan. Adapun tahap-tahap yang kami lakukan pada pengabdian ini meliputi:

\section{a. Observasi Kegiatan PKM}

Pada tahap awal kegiatan pengabdian kami melakukan observasi awal sebagai bahan pengabdian kami. Selain observasi kami melakukan wawancara dan audensi kepada Camat Semarang Selatan. Dari hasil observasi yang kami lakukan diperoleh data bahwa UMK di Kecamatan Semarang Selatan sebagian besar masih belum memiliki IUMK. Kemudian 


\section{Indonesian Journal of Community Services}

Volume 2, No. 1, May 2020

http://jurnal.unissula.ac.id/index.php/ijocs

DOI: http://dx.doi.org/10.30659/ijocs.2.1.1-10

disepakati untuk mengadakan penyuluhan hukum dan pendampingan dengan peserta perwakilan dari kelurahan yang ada.

\section{b. Penyuluhan Hukum dan Pendampingan}

Berdasarkan permasalahan yang ada maka pengabdian kami lakukan dengan beberapa kegiatan, salah satunya adalah penyuluhan hukum dan pendampingan. Penyuluhan hukum menggunakan metode ceramah dan tanya jawab. Pada acara pembukaan juga disampaikan kata pengantar dari ketua paguyuban UMKM Kecamatan Semarang Selatan yang mengapresiasi kegiatan penyuluhan ini karena dapat mendorong kemajuan usaha dan daya saing UMKM.

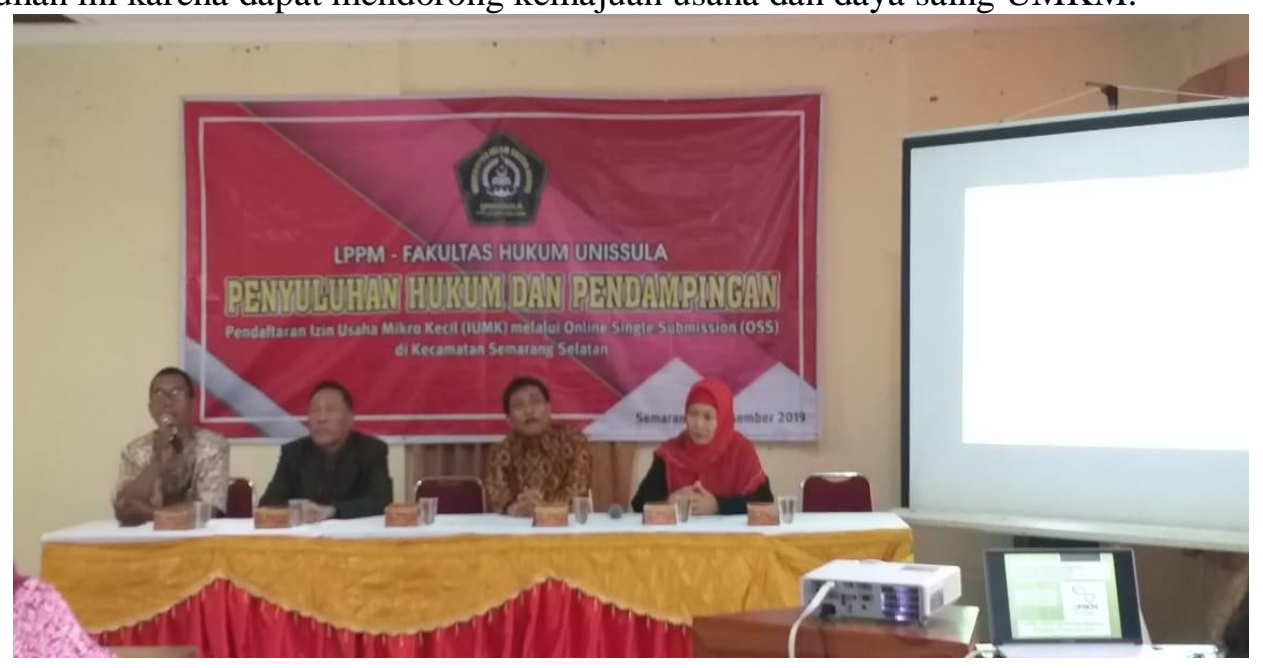

Gambar 1. Penyampaian kata pengantar dari ketua paguyuban UMKM Kecamatan Semarang Selatan

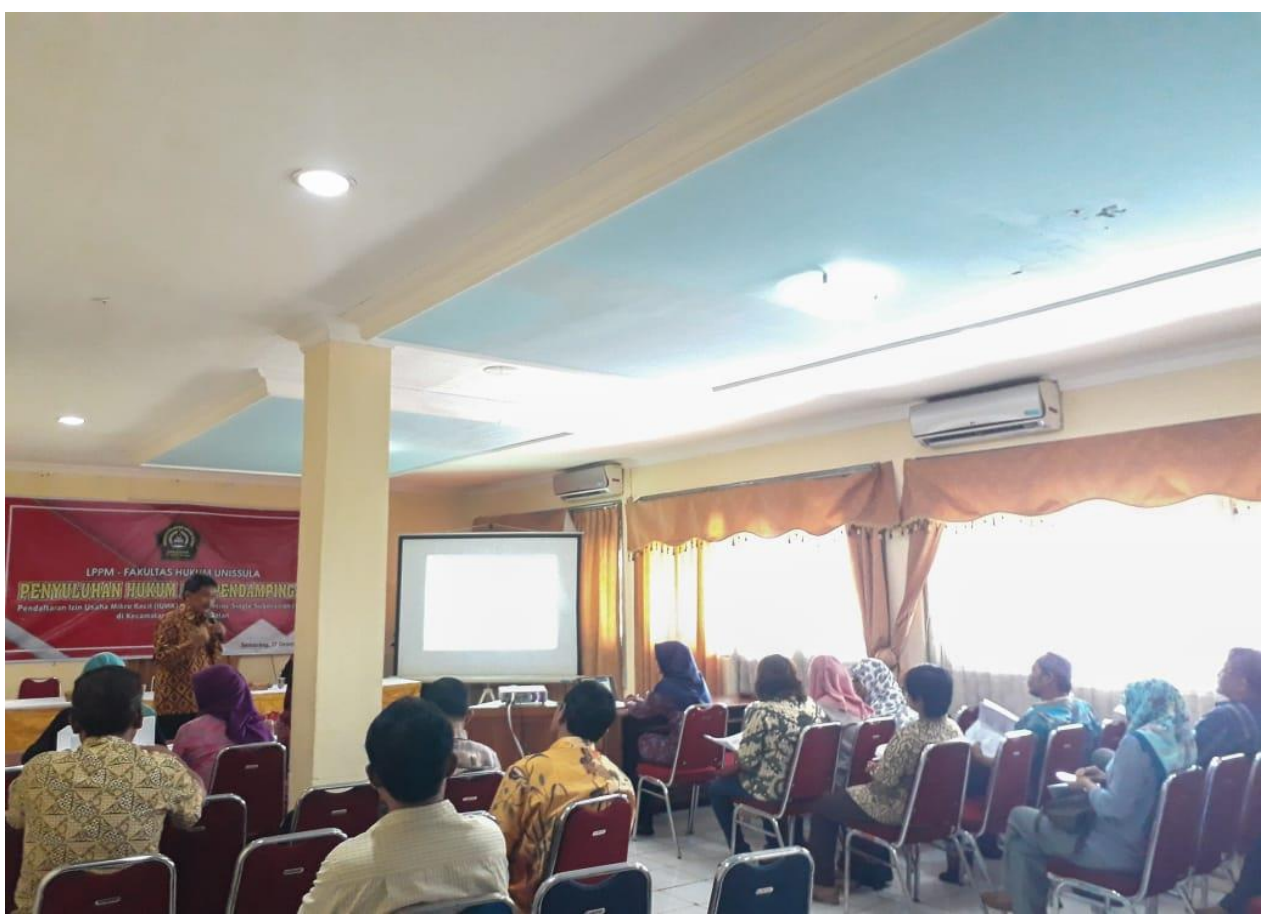

Gambar 2. Penyampaian materi penyuluhan hukum pendaftaran IUMK oleh pemateri 


\section{Indonesian Journal of Community Services}

Volume 2, No. 1, May 2020

http://jurnal.unissula.ac.id/index.php/ijocs

DOI: http://dx.doi.org/10.30659/ijocs.2.1.1-10

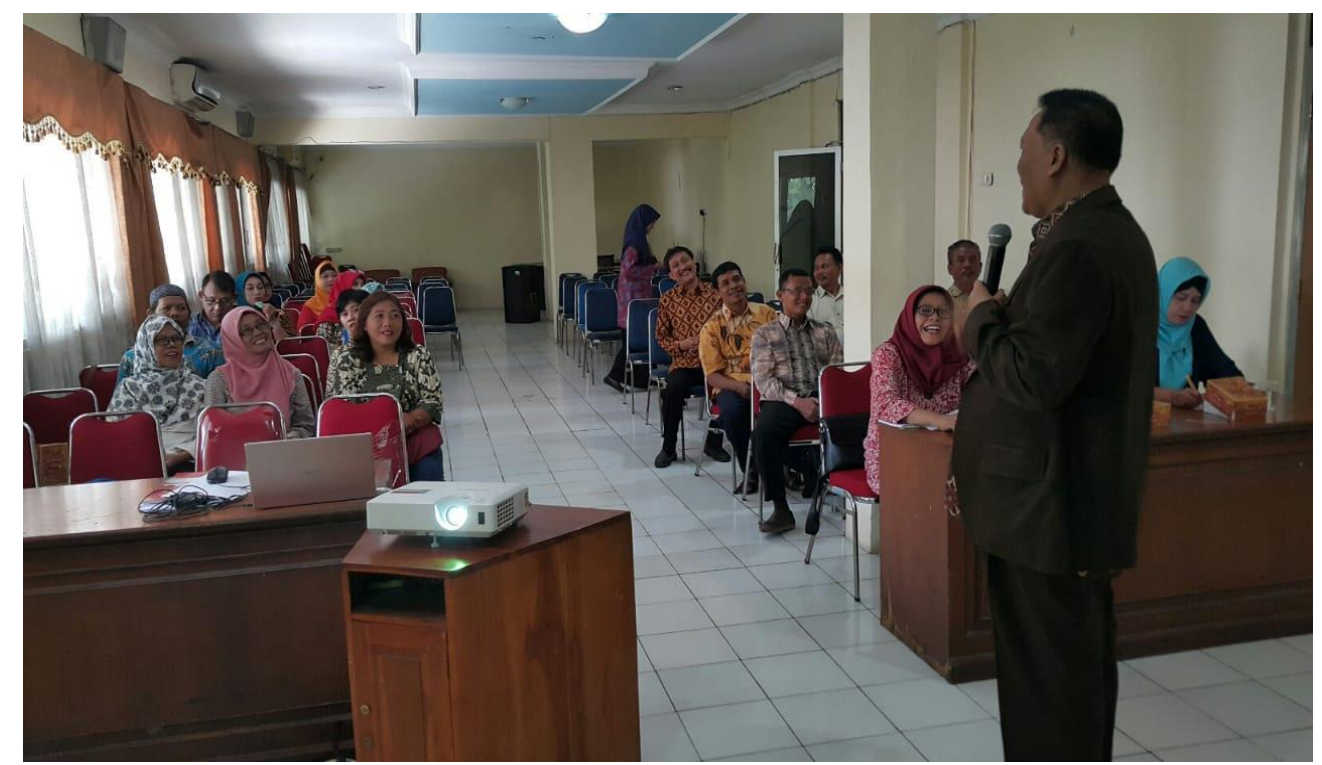

Gambar 3. Penyampaian materi membangun jiwa wirausaha yang handal oleh pemateri

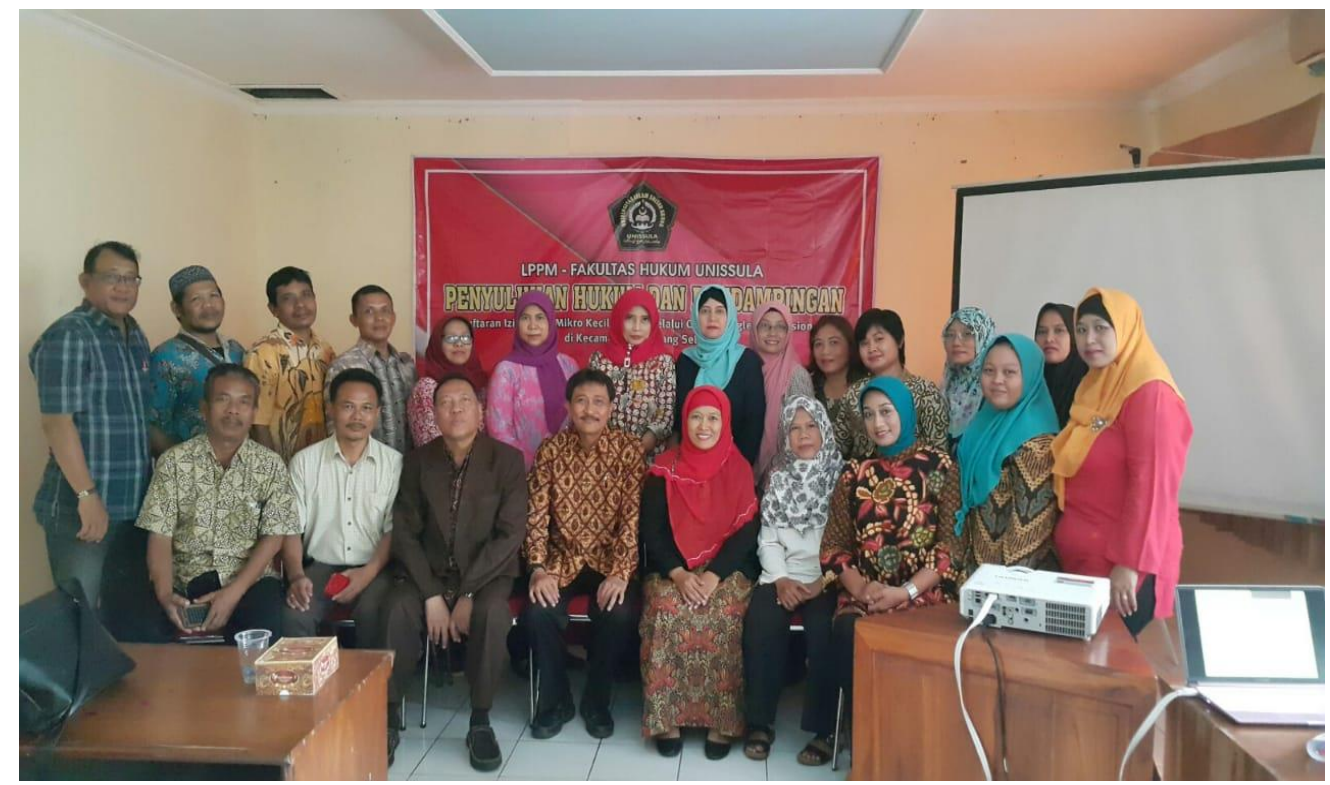

Gambar 4. Foto bersama peserta dan siap melakukan pendaftaran IUMK selesai acara pendampingan

\section{d. Pelaksanaan Kegiatan Pendampingan}

Pada rangkaian kegiatan pengabdian yang diadakan adalah dalam rangka memacu motivasi pelaku UMKM untuk mendaftarkan izin usahanya dan memperoleh IUMK. Dengan demikian, dari rangkaian kegiatan pengabdian kami mengadakan pendampingan dan bimbingan teknis pendaftaran yang dibantu langsung oleh petugas dari kantor kecamatan.

\section{e. Monitoring dan Evaluasi}

Tahapan akhir dari rangkaian kegiatan pengabdian masyarakat yang dilakukan adalah monitoring dan evaluasi. Selama kegiatan pengabdian masyarakat berlangsung dengan baik di 
aula kantor Kecamatan Semarang Selatan, berjalan dengan lancar dan memperoleh respon yang baik dari camat dan staf maupun para pelaku UMKM. Kegiatan monitoring yang kami lakukan adalah monitoring saat berlangsungnya kegiatan penyuluhan hukum, sosialisai, dan pendampingan. Hasil monitoring yang dilakukan terlihat setiap kegiatan berjalan sesuai dengan rencana. Estimasi dana dan waktu tidak banyak berubah. Materi yang disajikan tidak ada yang tertinggal. Pelaksanaan sesuai dengan tanggal yang telah disepakati pihak kecamatan dan tim pengabdian masyarakat. Pelaksanaan monitoring juga kami lakukan terhadap pendampingan pendaftaran IUMK di kecamatan. Kami sudah menyampaikan kepada semua peserta akan siap sedia, baik langsung maupun tidak untuk melaksanakan monitoring dan pendampingan jika ada UMKM yang berkenan. Hal ini memperoleh tanggapan yang baik dari para pelaku UMKM dan pihak kecamatan. Pendampingan yang kami lakukan sampai dengan terbitnya IUMK. Adapun evaluasi kami lakukan secara terus-menerus dan berkesinambungan. Selama pelaksanaan kegiatan kami juga menerima kritik dan masukan dari peserta.

Syarat-syarat untuk mendapatkan IUMK adalah: 1) mengisi formulir yang memuat tentang: nama, nomor KTP, nomor telepon, alamat, kegiatan usaha, sarana usaha yang digunakan, jumlah modal usaha 2) surat pengantar dari RT atau RW terkait lokasi usaha 3) Fotokopi Kartu Tanda Penduduk (KTP) 4) Fotokopi Kartu keluarga (KK) 5) Pas foto terbaru berwarna ukuran 4 x 6 (2 lembar) (Sumber: Permendagri No. 83 Tahun 2014).

Tahapan pengajuan IUMK: permohonan perizinan di kantor kecamatan secara online, pemohon mengisi formulir dan melengkapi dokumen persyaratan, pemohon membawa formulir dan dokumen persyaratan ke kantor kecamatan setempat, Camat menerima dan memeriksa kelengkapan dan kebenaran dari formulir dan dokumen persyaratan, pabila sudah lengkap dan benar, Camat akan memberikan naskah 1 lembar IUMK, Jika masih belum lengkap, Camat mengembalikan formulir dan dokumen persyaratan untuk dilengkapi oleh pemohon.

Permohonan perizinan secara online melalui 3 tahap yaitu: Tahap 1 membuat akun OSS Pemohon mengunjungi website https://www.oss.go.id/oss/., klik tombol "Daftar" di kanan atas, mengisi formulir yang ada di layar. Tahap 2: Masuk ke akun OSS dan mengisi data. Tahap 3: Mengunduh Nomor Induk Berusaha (NIB) dan IUMK. (Sumber: Permendagri No. 83 Tahun 2014 dan https://www.oss.go.id/oss/ )

\section{HASIL DAN PEMBAHASAN}

Dengan adanya pelaksanaan pengabdian kepada masyarakat di Kecamatan Semarang Selatan dapat memberikan banyak manfaat kepada pelaku UMKM. Izin Usaha Mikro Kecil sebelumnya hanya dipandang sebagai tidak penting dan merepotkan pengurusannya, namun ternyata sangat mereka perlukan dalam mendorong pertumbuhan dan daya saing usahanya. IUMK ini telah terintegrasi dengan akses permodalan Kredit Usaha Rakyat (KUR) dari BRI.

Sejak awal tahun 2019, sudah disosialisasikan bahwa pengurusan IUMK sebagai izin usaha dalam Sektor Perkoperasian dan Usaha Mikro, Kecil dan Menengah dapat melalui Online Single Submission (OSS). Yang harus diingat adalah pelaku usaha memiliki alamat e-mail yang aktif dan password yang mudah diingat. Serta nomor HP yang bisa dihubungi. Adapun link untuk mendaftar melalui OSS : https://www.oss.go.id/oss/.

Lokasi usaha harus sesuai dengan alamat di KTP dan KK, karena berkaitan dengan surat pengantar dari RT atau RW. Jika tidak sesuai, maka surat pengantar baru harus dibuat atau pilihan lain adalah membuat KTP dan KK yang alamatnya disesuaikan dengan lokasi usaha. Camat setempat sudah diberikan wewenang dari Bupati atau Walikota setempat untuk bisa memberikan IUMK. Pemberian wewenang juga dapat dilakukan oleh Bupati dan Walikota kepada Lurah/Kepala Desa sesuai dengan karakteristik wilayah.

Pendataan yang dilakukan oleh Camat, selaku pihak yang menerbitkan IUMK, berdasarkan: identias pelaku usaha mikro dan kecil, lokasi pelaku usaha mikro dan kecil yang berada di wilayah kecamatan, jenis tempat usaha, bidang usaha, dan besarnya modal usaha. 
Pelaku usaha mikro dan kecil memiliki hak antara lain: melakukan kegiatan usaha, mendapatkan informasi dan sosialisasi atau pemberitahuan terkait dengan kegiatan usaha, mendapatkan kepastian dan perlindungan dalam berusaha di lokasi yang telah ditetapkan, mendapatkan pendampingan untuk pengembangan usaha, mendapatkan kemudahan dalam akses pembiayaan ke lembaga keuangan bank dan non-bank, mendapatkan pembinaan dan kemudahan dalam pemberdayaan dari pemerintah, pemerintah daerah dan/atau lembaga lainnya. Pembinaan meliputi: pendataan, fasilitasi akses permodalan, penguatan kelembagaan, pembinaan dan pendampingan bimbingan teknis, dan mengembangkan kemitraan dengan dunia usaha.

Fungsi negara dalam bidang ekonomi, menurut Friedman (dalam Wacks, 2009) yaitu sebagai penjamin (provider) kesejahteraan rakyat, negara sebagai pengatur (regulator), negara sebagai pengusaha (entrepreneur) atau menjalankan sektor-sektor tertentu melalui Badan Usaha Milik Negara (BUMN), dan negara sebagai wasit (umpire) untuk merumuskan standar-standar yang adil mengenai sektor ekonomi termasuk perusahaan negara (state corporation).

Pembangunan nasional merupakan proses perubahan struktural yang dilakukan secara terus menerus dan berkesinambungan. Pembangunan adalah proses natural untuk mewujudkan cita-cita bernegara, yaitu masyarakat makmur sejahtera, adil, dan merata. Proses natural tersebut dapat terlaksana jika asumsi-asumsi pembangunan dapat dipenuhi, yaitu kesempatan kerja atau partisipasi termanfaatkan secara penuh (full employment), setiap orang memiliki kemampuan yang sama (equal productivity, equal access, level playing field), dan masing-masing pelaku bertindak rasional (efficient) (Sumodiningrat, 2001).

Todaro (1994) berpendapat, pembangunan adalah proses multidimiensional yang melibatkan perubahan-perubahan mendasar dalam struktur sosial, perilaku sosial, dan institusi nasional. Di samping itu, akselerasi pertumbuhan ekonomi, pengurangan ketidakmerataan, dan pemberantasan kemiskinan juga diagendakan.

Kemiskinan merupakan masalah kronis yang melanda bangsa Indonesia. Berdasarkan laporan Microcredit Summit tahun 2002 (Amalia, 2009), jumlah penduduk dunia yang hidup di bawah garis kemiskinan diperkirakan sekitar 235 juta keluarga, sebagian diantaranya yaitu 157,8 juta $(67 \%)$ ada di negara-negara Asia. Salah satu upaya penanggulangan kemiskinan adalah dengan memutus mata rantai kemiskinan melalui pemberdayaan kelompok masyarakat yang memiliki usaha pada sektor paling kecil (UKM).

Dengan adanya pelaksanaan pengabdian kepada masyarakat di Kecamatan Semarang Selatan dapat memberikan banyak manfaat kepada pelaku usaha menengah kecil. Izin usaha sebelumnya hanya dipandang sebagai membebani mereka baik dalam hal pengurusan pendaftarannya, biaya, maupun aspek manfaatnya. Namun, ternyata setelah diberikan penjelasan mengenai pelaksanaan pendaftaran yang sangat mudah, cepat, dan tanpa dipungut biaya, disamping manfaat yang akan diperoleh dengan dimilikinya izin usaha, mereka menjadi sangat antusias untuk mengurus izin usahanya.

IUMK menjadi daya tarik mereka karena dengan memiliki IUMK akan dapat mengakses modal melalui Kredit Usaha Rakyat (KUR) Bank Rakyat Indonesia (BRI). Akhirnya memiliki IUMK menjadi hal yang penting untuk mendorong pertumbuhan dan daya saing UMKM. Oleh karena itu, dengan adanya penyuluhan hukum tentang pendaftaran IUMK menjadikan pelaku UMKM memiliki kesadaran dan kepatuhan hukum yang meningkat khususnya aspek legalitas usahanya. Pelaku UMKM mendapatkan pengetahuan dan informasi tentang pendaftaran izin usaha serta motivasi untuk terus berwirausaha agar semakin maju bisnisnya.

Penyuluhan hukum ini menjadi lebih hidup karena mereka dapat saling berinteraksi membuat jejaring, dan tukar pengalaman dalam menjalankan usahanya. Maka, pengabdian masyarakat ini memiliki sasaran yang tepat yaitu dengan mendorong UMK memiliki IUMK dengan harapan usahanya akan semakin maju dan berkembang. 


\section{KESIMPULAN}

Pengabdian masyarakat tentang Pendaftaran Izin Usaha Menengah Kecil (IUMK) melalui Sistem Online Single Submission (OSS) di Kota Semarang ini telah dapat mendorong kesadaran dan kepatuhan hukum pelaku usaha UMK untuk mendaftarkan izin usahanya dan memiliki IUMK. Mereka menjadi sadar bahwa pemenuhan aspek legalitas usaha dengan meiliki IUMK akan meningkatkan pertumbuhan dan daya saing UMK. Aspek legalitas yang memperhatikan kepentingan dunia usaha (business friendly) perlu dijadikan paradigma baru. Disamping itu, sosialisasi dan edukasi kepada pelaku usaha UMK terkait kewajiban pendaftaran perizinan melalui OSS perlu lebih ditingkatkan. Karena kegiatan penyuluhan dan pendampingan tersebut ternyata dapat mempengaruhi kepatuhan UMK untuk mengurus izin usahanya.

\section{UCAPAN TERIMA KASIH}

Tim pelaksana pengabdian mengucapkan terima kasih kepada Camat Semarang Selatan dan pelaku UMK yang telah menjadi mitra dalam pelaksanaan pengabdian ini, Lembaga Penelitian dan Pengabdian Masyarakat (LPPM) UNISSULA, Dekan FH UNISSULA serta pihak terkait lain yang telah membantu selama kegiatan.

\section{DAFTAR PUSTAKA}

Amalia, E. (2009). Keadilan Distributif dalam Ekonomi Islam Penguatan Peran LKM dan UKM di Indonesia, Jakarta: RajaGrafindo Persada

Fatimah, S., Kartika, I., \& Niyartama, T. F. (2012). Pembelajaran fisika menggunakan model cooperative learning ditinjau dari prestasi belajar siswa. Jurnal Kependidikan: Penelitian Inovasi Pembelajaran, 42(1).

Manurung, A.H. (2008). Modal untuk Bisnis UKM. Jakarta: Gramedia.

Peraturan Menteri Dalam Negeri No.83 Tahun 2014 tentang Pedoman Pemberian Izin Usaha Mikro dan Kecil

Peraturan Pemerintah Nomor 17 Tahun 2013 tentang Pelaksanaan Undang-undang Nomor 20 Tahun 2008 tentang Usaha Mikro, Kecil dan Menengah

Peraturan Daerah Provinsi Jawa Tengah Nomor 13 Tahun 2013 tentang Pemberdayaan Usaha Mikro, Kecil, dan Menengah.

Purnawan, A. (2011). "Rekonstruksi Sistem Pemungutan Pajak Penghasilan (PPh) Badan Berbasis Nilai Keadilan" dalam Jurnal Dinamika Hukum Terakreditasi, ISSN 1410-0797, Vol. 11 Edisi Khusus Februari.

Purnawan, A., \& Adillah, S.U. (2014). "Pengembangan Desain Tax Policy Daerah Berbasis Keadilan untuk Mendorong Pertumbuhan Usaha Kecil Menengah (UKM) di Jawa Tengah" Penelitian Hibah Unggulan Perguruan Tinggi. Semarang: Fakultas Hukum Unissula.

Purnawan, A. (2019). Problematika Pelaksanaan Pendaftaran Usaha UMKM melalui Sistem Online Single Submission (OSS) di Kota Semarang. Laporan Penelitian Internal LPPM Unissula, Semarang: Fakultas Hukum Unissula. 
Sulistyo, H., Wuryanti, \& Siyamtinah. (2014). Keunggulan Bersaing UMKM tenun Jawa Tengah berbasis organizational knowledge assets \& CRM. Laporan Penelitan Hibah Dikti. Semarang: FE Unissula

Sumodiningrat, G. (2001). "Kepemimpinan dan Pemberdayaan Ekonomi Rakyat". Naskah Pidato Pidato Pengukuhan Jabatan Guru Besar pada Fakultas Ekonomi Universitas Gadjah Mada 17 Maret 2001. Yogyakarta: UGM

Todaro, M. (1994). Economic Development. Singapore: Longman Singapore Publisher

Undang-undang Nomor 20 Tahun 2008 tentang Usaha Mikro, Kecil dan Menengah.

Wacks, R. (2009). Understanding jurisprudence: An introduction to legal theory. New York: Oxford University Press. 